\title{
život umjetnosti
}




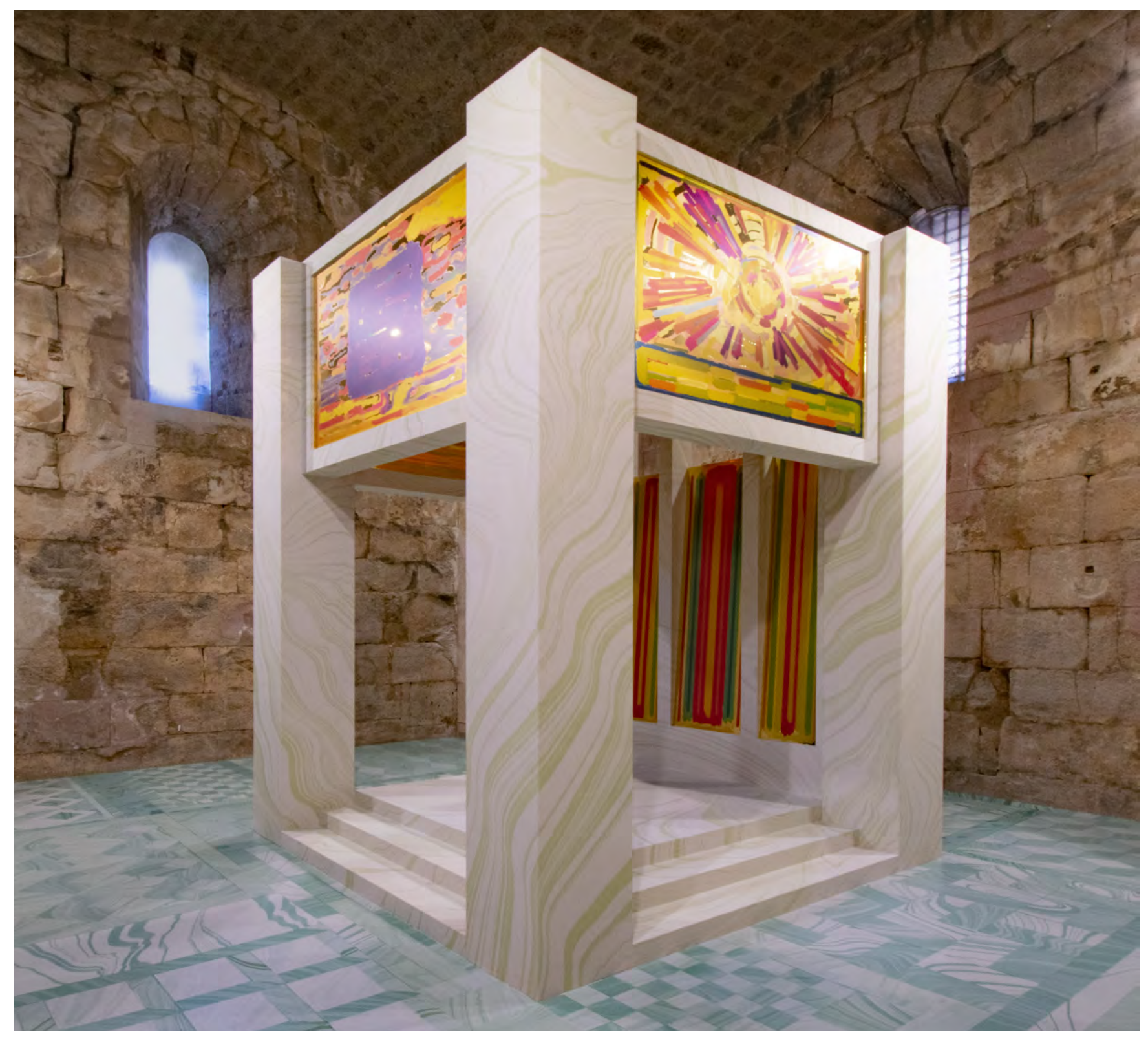

Peter Halley and Lauren Clay, Qube, 20I9. Photo: Peter Halley and Lauren Clay, 2019. Courtesy: Peter Halley and Lauren Clay 


\section{Conversational Form - An Interview with Peter Halley and Lauren Clay}

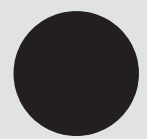

Peter Halley ef Lauren Clay: Qube

Kula Gallery, Split, July 23 -September 24 , 2019

DOI: $10.31664 / z u .2019 .105 .10$

This year's program in the Art Gallery Kula in Split features an absorbing visit by two American artists, Peter Halley and Lauren Clay. Stemming from the I980s when he began to implement his orientation towards New Geometry, Peter Halley is the protagonist of postmodern visual art movements, both through his intense painting practice and his inspired writing of analytical essays. He has always intelligibly expressed his personal fascination with Michel Foucault's theoretical thought, building upon it as his conceptual foundation, and has reactivated this philosophy in recent shows that he has conceived of as collaborative art platforms. On the other hand, Lauren Clay is an artist of a younger generation who artistically explores diverse visual phenomena, mostly in three-dimensional media, by using peripheral spatial forms as triggers for the formation of her works and their various semantic layers.

\section{Dalibor Prančević}

Department of Art History, Faculty of Humanities and Social Sciences, University of Split

\section{Lucija Ečim}

Independent researcher, Split 
The collaboration between Peter Halley and Lauren Clay emerged with a monumental joint installation in the Paradise City Hotel in Seoul, South Korea (2OI7), along with an ambient artwork, Heterotopia I (20I9). Heterotopia I was imbued with significant postmodern references and was realized, together with Andrew Kuo and R. M. Fischer (in organization of Flash Art and the Academy of Fine Arts in Venice) during the Venice Biennale. The third artistic collaboration of Halley and Clay, entitled Qube, was manifested in one of Croatia's oldest exhibition spaces, the Late Antique tower of Diocletian's Palace in Split. The robust stone membrane of the historic structure meets with the contemporary art lexis and material introduced by the artists. The juxtaposition of the old, Late Antique wall complex with the new work, creates a rupture in time that results in semantical uncertainty. In other words, this contiguity stimulates a dialectical symbiosis of the two "tectonic" realities.

In highlighting their collaborative association in the form of a transcribed and authorized interview, we are most pleased to bring you here in its entirety, Halley and Clay speak directly about the genesis of their own artistic activities, their entwined experience over the years and their joint project in Split. 
Lucija Ečim (LE) Peter Halley (PH) Lauren Clay（나)

LE Peter, you went to high school at Phillips Academy in Andover, Massachusetts, studied art history at Yale University, and received an MFA in painting from the University of New Orleans. When exactly did your interest for abstract painting begin?

PH I started to become interested in abstract painting while I was a student at Phillips Academy. The school had an art program that was influenced by Bauhaus teaching methods, so my earliest training was based on modernist ideas. Also, I'm from New York City. So I grew up in a place where contemporary art was very much a part of the local landscape.

LE After you graduated from Yale University, you moved to New Orleans.

PH Yes. I fell in love with New Orleans on my first visit. I spent five or six years there. The city was very influential on me. After that, I moved back to New York.

LE What influence did New Orleans have on you?

PH Well, I had never lived anywhere other than the northeast United States, so living in New Orleans was almost like living in another country. It was completely different and very appealing in terms of its architecture and culture. New Orleans is a city with a truly distinct local culture going back 200 years.

LE In one interview, you talked about the feeling of isolation living by yourself in an apartment after moving to New York in I980. Is this what inspired the geometric vocabulary of your paintings that feature "prisons," "cells" and "conduits?"

PH I was already making abstract geometric work in New Orleans. However, I began to understand geometry differently when I moved to New York. I began to think that geometric abstraction in twentieth-century art was related to the way geometric systems had begun to dominate our physical environment, especially the connections, the conduits, between places. When I arrived in the city, I was living alone in the East Village. I didn't have a lot of friends at the time, so I did feel isolated at home. However, I gradually realized that, when I talked on the telephone, or turned on the lights, or ran the water, I was connected to people through technological networks that provided the connections. It helped me to understand the Internet when that came along. It's a result of the same phenomenon.

LE You belong to the generation that was influenced by the expanding influence of media and popular culture. How do you think this has changed artists' view of nature?

PH Yes, I think I do belong to that generation. But I've always been more interested in underlying technological structures than in mass culture. To me, the geometrization of culture and the environment in the twentieth century meant that our experience of nature became completely mediated. We started living in environments in which we became more and more dependent on technologyair conditioning, electric lights, automobiles. By the $8 \mathrm{os}$, this led a lot of artists and philosophers to question the prevailing idea that nature was the ultimate reference point for reality.

LE You've said that Andy Warhol has had an immense impact on you as an artist. How did it feel when he asked if he could take your portrait?

PH Well, I didn't want to do it. 
LE Why?

PH Because I thought only celebrities had their portraits done by Warhol. But when I visited his studio, I realized that everybody there assumed that he was going to do my portrait. So I sat down and he took some photos.

LE How did New Wave music influence your work?

PH The band that probably influenced me the most was the Talking Heads. Their music is almost like Pop Art. The early 80 s in America and Europe were dominated by Neo-Expressionism, which was not very interesting to me. The artists of my generation were looking at Pop Art and Minimalism again-bringing back those influences that had been rejected by the Neo-Expressionists.

LE Your installation, Heterotopia I, was presented in conjunction with this year's Venice Biennale. "Heterotopia” is a concept created by Michel Foucault. In what ways did Foucault's ideas influence your work?

PH Foucault was a major influence. He helped me understand how spaces built by people influence and determine the way we live our lives. Another philosopher who talked about social space was Guy Debord, who was also important to me. Reading Foucault and Debord gave me the confidence that the diagrams of space I was developing in my paintings made sense.

LE You work with a team of assistants in your studio. Can you explain the process of creating a painting from beginning to end?

PH I begin with the compositional study that I draw on the computer. I started drawing on the computer in I993. It really influenced my work because it made it so easy to change shapes and proportions. You can make things wider or taller, or add or subtract elements so easily. This was especially useful for me, since I'll sometimes change just one element of an existing composition to create a different painting. I then print the drawing on paper and make a painted color study. After that, the stretcher is ordered, and then we build up the thick texture with layer after layer of paint. Two artists do that for me in my studio. It takes a couple of weeks.

LE Lauren, you are an interdisciplinary artist with experience in painting, sculpture and installation. How would you describe your art?

LC I create large scale digitally printed wall installations and wall-based relief sculptures. I received a BFA in Painting from Savannah College of Art and Design in 2004. I went on to receive an MFA in Painting from Virginia Commonwealth University in 2007. Even though I studied painting in school, my work slowly became more and more sculptural over time. My work often references architecture and I'm interested in exploring the ways in which I can expand and distort space in my sculptures and installations.

LE Since all your works abound with color and texture, what is the first thing you think about when you start planning an installation?

LC I usually begin by studying the architecture of the gallery. My installation work is often site-specific so I make a model of the space and study it. I'm usually inspired to somehow distort or exaggerate an existing aspect of the space. Studying the architecture of Galerija Kula and of Diocletian's palace was an important first step for this installation. 
LE You use a marbling technique quite a lot in your work. Why? Could you describe the process?

LC I taught myself to marble paper when I made a series of paper sculptures referencing the American artist David Smith. From that point I continued using marbling in my work. In paper marbling, you float pigments on a thick liquid and then lay down a sheet of paper which captures the floating pigments. When you do this, you also capture all of the ripples and dimensionality of the liquid surface. I became really interested in the way a flat sheet of paper can look so distorted because of the captured ripples and movements in the liquid. I started scanning the marbled paper and enlarging it and printing it for huge room-sized installations. When enlarged and printed as wallpaper, the marbled paper has the same effect-it distorts and warps the viewer's perception of an otherwise flat wall.

LE In one interview you said that music sometimes influences you more than visual art. Is that true?

LC Yes, at times in my life this has been true-music has an important place in my life. In relation to this, I was also influenced early on by reading about the I960's counter-culture movement and studies about psychedelia. I identify with the I960's ethos of prioritizing the experiential and the bodily experience of the viewer. I'm also interested in decorative arts, and architecture. Lately, I look at Italian architecture, especially from the Italian Baroque, because they were doing so many interesting things to distort space in mural painting and in low-relief architectural facades. I also love interesting uses of marble in churches, and faux marble painting techniques. I've been lucky to travel a lot in Europe the last few years, but not so much in the States, unfortunately.

LE What other artists have you collaborated with?

LC Well, this might be my first true collaboration. Peter and I have done a few projects together but otherwise I've always worked on my own. Collaborating with Peter developed naturally. We're interested in many similar things, so our relationship progressed to the point where we started working together.

PH And we've done three projects together.

LE Could you tell me something about those projects?

PH Our first project was for a hotel lobby in Seoul, Korea. I made paintings that were placed against a big digitally-printed mural of Lauren's. The second project was only partly a collaboration. Lauren designed a room for the exhibition at the Biennale, Heterotopia I. It was fun.

LE Could you explain how Qube came to life?

LC When we first saw images of the gallery, we were blown away by the space's history and the idea of having a show there. We spent a long time studying the architecture. We both built models in our studios and we looked at them together just as much as we looked at the photos of the gallery. We didn't want to do a conventional show by building walls and hanging paintings or prints. We wanted to expose the original stone walls, so we decided to build a structure in the center of the space which could somehow contain the art. The idea evolved from there. We both love antiquities and looking at architecture together, especially Roman architecture, so for the structure I started by referencing the Ara Pacis. This gallery also has a kind of mystical, hidden, tucked away type of feel and we wanted to accentuate that by creating an altar-like structure that the viewer could enter. 
PH I'm interested in paintings that exist within architecture. I like Baroque churches or palaces in which the architecture allows for paintings in certain places. This exhibition is the first time that I have ever been able to place works in a specifically designed architectural structure made to house those works.

LE Do you generally have similar views and attitudes about what art should be?

PH No, I wouldn't go that far.

LC Me neither.

PH People can have the same interests but do entirely different things. I could never make this structure myself. I would probably be drawn to do something different because I'm not a sculptor.

LC We share a lot of common interests, but we also disagree on many things. Our differences are usually a positive aspect of the collaboration - we both bring different references, ideas and experiences to the project. Even when we disagree, we have interesting conversations!

PH I think there is one thing we do agree on. People have forgotten about history, es pecially in the last decade or two. Lauren and I are both driven towards projects which have a lot of historical references and which are designed to create puzzles about history. Lately I feel an impulse to make things that are more complex and layered. I'm reacting to what I see as a lack of intellectual complexity in a lot of recent contemporary art. 
